\title{
Development of Junior High School Mathematics E-Modules Based on Project Based Learning Integrated by Merdeka Belajar
}

\author{
Prihatin Ningsih Sagala ${ }^{1, *}$ Eri Widyastuti ${ }^{2}$ \\ ${ }^{1,2}$ Universitas Negeri Medan, Jl. Williem Iskandar Pasar V Medan Estate, Indonesia 1,2 \\ ${ }^{*}$ Corresponding author. Email: Alfathmommy81@gmail.com
}

\begin{abstract}
Ki Hajar Dewantara argues that Merdeka Belajar is the freedom given to student seeking all knowledge by themselves using their minds. Project-based learning will accommodate student independence because it will result in higher student engagement and deep concept understanding. The development of SMP Mathematics E-modules in the form of the latest interactive project-based learning e-modules that are integrated with Merdeka Belajar is very necessary because interactive e-modules can help today's students to be actively involved in learning. Some of the features available in the Junior High School Mathematics E-book include instructions for using the e-modules, concept map feature, being able to embed YouTube links, google form links, teacher audio/voice features to explain the learning objectives of each chapter, teacher presentation videos, assignment links. students, and student evaluation links. All of these features make e-books interesting and interactive.The purpose of this study was to obtain an E-module Mathematics for SMP class VII based on project-based learning integrated that was feasible from the aspect of validity and practicality. The results showed that the validity aspect obtained from the assessment of material and media validators was 3.67 with a very decent category. Based on the practical aspect, the responses of students and mathematics teachers were $3.50(87.5 \%)$ and $3.64(91 \%)$ in the very practical category, respectively. The conclusion is that the integrated interactive e-module of Merdeka Learning is declared very feasible and very practical to be used in the mathematics learning process for class VII SMP.
\end{abstract}

Keywords: Merdeka Belajar, E-Modules, Integrated.

\section{INTRODUCTION}

Merdeka Belajar is an initiative program of the Minister of Education and Technology Nadiem Makarim which aims to create a pleasant learning atmosphere for students and teachers [1]. Merdeka Learning was born from the many complaints of parents on the national education system. One complaint is that many students are pegged to certain values as a measure of learning success. Freedom to learn is one of the efforts to freedom in thinking and expression [2]. Basically this program aims to liberate teachers and students in accordance with the spirit of the Father of National Education, Ki Hadjar Dewantara. Freedom to Learn is the initial foundation where the seeds of culture reside. Students are given the freedom to access knowledge [3]. Sources of knowledge are not only limited to classrooms, teachers, but can be outside the classroom, in online or internet media, libraries, and also in the surrounding environment. Teachers become directors, mentors and facilitators of student learning [3], [4].

In addition, the new challenge of the COVID-19 pandemic has changed the order of life very quickly, including the implementation of the learning process which was originally face-to-face learning in schools to online learning at home. These challenges certainly go hand in hand with various opportunities, such as advances in science and technology as well as the demographic bonus in 2045. Therefore, education must be able to produce quality outputs in the form of Human Resources who have the skills and competencies so that they can respond positively to challenges by utilizing various opportunity [5], [6]. The independent learning concept initiative is one solution to make it easier for teachers and students to interact virtually in online 
learning [4], [7]. So that during the current pandemic, schools do not become a new cluster of additional cases of Covid-19. Project-based learning is an alternative for implementing learning in schools. Although of course online learning needs to be combined with offline learning while still implementing the 5M Prokes called blended learning.

Project Based Learning is a learning model that uses projects as the core of learning. This learning model is an innovative learning model that involves project work where students work independently in constructing their learning and culminating it in real products [8]. The following are some definitions of Project Based Learning from several book sources, namely (1) According to the NYC Department of Education [9], the Project Based Learning learning model is a learning strategy where students must build their own content knowledge and demonstrate new understanding through various forms of representation. (2) According to the Buck Institute for Education, the Project Based Learning learning model is a systematic teaching method that involves students in learning knowledge and skills through a structured process, real and thorough experience designed to produce products [10]. (3) Project Based Learning is a way of learning that gives students freedom of thought related to the content or teaching materials and planned goals [11]. (4) According to Boss and Kraus, Project Based Learning Model is a learning model that emphasizes student activities in solving various openended problems and applying their knowledge in working on a project to produce a certain authentic product [12].

Project based learning provides opportunities for students to expand learning materials and develop skills through problem solving and investigation. In PjBL students can practice how to make decisions based on real-life problems. Students can develop skills, think critically and apply knowledge in making a project that will solve the problem presented. Students can gain invaluable experience by doing and actively participating in the learning process. Compared to just reading the information presented in the lesson and then taking the test at the end of the lesson on e-learning. In terms of characteristics, the Project Based Learning learning model has several characteristics, namely as follows: (1) Developing questions or problems, which means learning must develop the knowledge possessed by students. (2) Having a relationship with the real world, means that learning is authentic and students are faced with problems that exist in the real world. (3) Emphasizing on the responsibility of students, is the process of students to access information to find solutions that are being faced. (4) Assessment is carried out during the learning process and the results of projects carried out by students. Meanwhile, according to Stripling, the Project Based Learning model has the following seven characteristics [14]: (1) Directing students to investigate important ideas and questions.(2) It is a process of inquiry. (3) Related to the needs and interests of students. (3) Student-centred by making products and making presentations independently. (4) Using creative, critical, and information seeking skills to conduct investigations, draw conclusions, and produce products. (5) Related to authentic real-world problems and issues.

According to Thomas, project-based learning has several principles in its application, namely [15]: (1) Centralized. This learning model is the center of the learning strategy, because students learn the main concepts of knowledge through project work. Project work is central to the learning activities carried out by students in the classroom. (2) Guide Questions. Project work carried out by students is based on questions or problems that lead students to find concepts about certain fields. In this case work activities become external motivation that can generate internal motivation in students to build independence in completing tasks. (3) Constructive Investigation. Project-based learning is an investigative process carried out by students to formulate the knowledge needed to work on projects. Therefore, the teacher must be able to design learning strategies that encourage students to carry out the process of searching and or deepening the concept of knowledge in order to solve the problems or projects they face. (4) Autonomy. Project-based learning, students are given the freedom or autonomy to determine their own targets and are responsible for what they do. The teacher acts as a motivator and facilitator to support student success in learning. (5) Realistic. Projects carried out by students are real work that is in accordance with the reality in the field of work or in the community. Projects that are carried out are not in the form of simulations or imitations, but work or problems that are really real.

Based on the results of observations and interviews of the research team at MTs Negeri 2 Medan and at SMPIT Alhijrah 2 Deli Serdang, it shows that schools have technological facilities, such as computer laboratories, wifi, LCD projectors, and gadgets. But the reality the teaching materials used when learning are only textbooks and printed modules. Even though the potential in schools is very adequate, including laptops which are almost owned by all teachers and students but are not used optimally in the implementation of learning. In addition, the condition of learning mathematics during the COVID-19 pandemic using the distance learning method is still difficult because its implementation in schools is only based on collecting assignments. Students also cannot understand the subject matter because of the absence of physical teaching and learning activities. Several previous studies revealed that there are products that are suitable to be used as learning modules including; development of active learning-based mathematics modules to facilitate the mathematical creative thinking skills of junior high school students [16], development of mathematics learning modules containing emotional quotients on the subject of sets [17], and development of 
mathematics modules on statistics material to facilitate static reasoning for class VIII SMP/MTs students [18]. In line with the KARMADATI Journal vol.7 2018 with the title of developing an e-module based on project-based learning for class IX visual effects, with a theory proportion of $30 \%$ and project practice $70 \%$, it was found that the percentage of module content achievement levels reached $91.83 \%$ with very good qualifications [19].

Based on previous research, it supports researchers to develop up-to-date mathematics learning teaching materials in the form of e-modules for Junior High School Mathematics for grade VII based on Project Based learning, integrated independent learning. The development of these teaching materials is necessary because there is still a lack of use of interactive e-modules that are integrated with independent learning in one of the subject matter that is very important for students. The use of teaching materials in the mathematics learning process has an important role as an intermediary that can help clarify the ambiguity of the material. Teaching materials can be packaged in printed and non-printed forms such as books, modules, worksheets with the help of electronic media, namely: video, audio, multimedia presentations and can also use online and offline content [7]. When viewed from the characteristics of Generation Z, students of today's generation no longer like printed reading materials but prefer digital reading materials [20]. One of the most important aspects in today's learning is the development of teaching materials in the form of electronic modules and material delivery strategies [5]. The use of teaching materials in the mathematics learning process has an important role as an intermediary that can help clarify the ambiguity of the material. In particular, [21] recommends the need for the use of technology in statistics learning that can encourage students to become active learners and help students understand concepts and not just acquire numeracy skills. This is believed to increase interest, motivation, and understanding in learning statistics which in the conventional approach is very theoretical and boring [22].

\section{METHOD}

\subsection{Place of Research}

This research was conducted at MTs Negeri 2 Medan, which is located at J1. Peratun, No. 3, Ex. Sidorejo Hilir, Kec. Medan Tembung, Medan City, North Sumatra. This research and product trial was carried out during the semester and adjusted to the class VII math schedule at MTs Negeri 2 Medan for the 2020/2021 academic year.

\subsection{The Research Method}

Method used by the researcher is research on the development of 4D devices from Sivasailam Thiagarajan, Dorothy S. Semmel, and Melvyn I. Semmel., as the suggestions chosen for the learning device development model [23], [24] stated the 4D development model as follows.

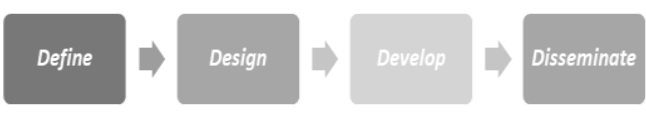

Figure 1 4D Development steps

\subsection{Reseach and Development Procedure}

Research and Development Procedures integrated interactive e-module independent learning on statistical material using the 4D device development research method (Four D Model) from Sivasailam Thiagarajan, Dorothy S. Semmel, and Melvyn I. Semmel. The 4D development model is the chosen suggestion for the learning device development model [23]. The four stages can be seen in the following chart.

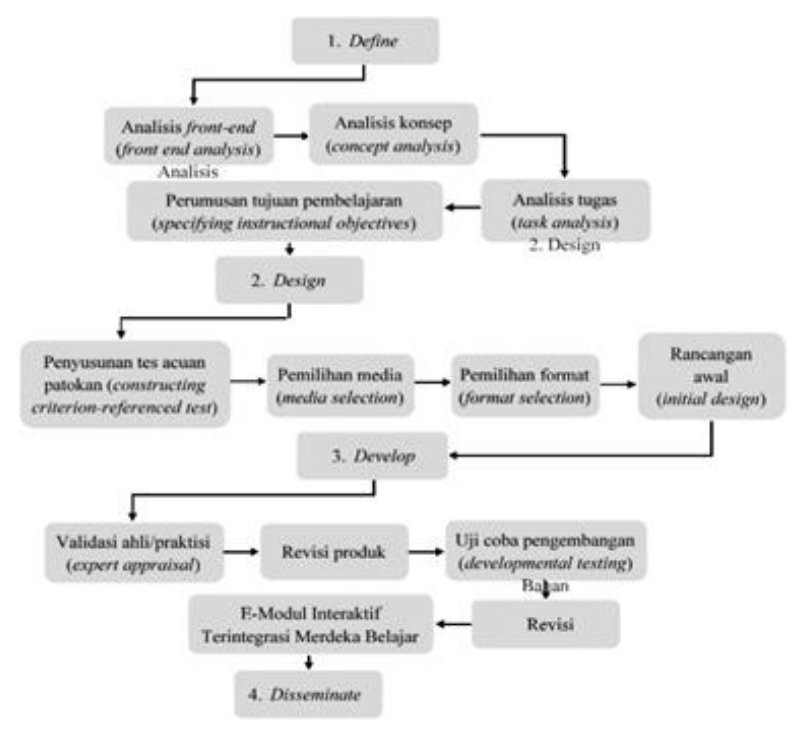

Figure 2 Research model for development of 4D devices.

\section{ANALYSIS DATA}

Analysis to be carried out by Expert Validation is Content Analysis (Material) from 2 validators / Mathematics lecturers and media analysis from 2 validators / IT lecturers. With the criteria according [25] to the table below.

Table 1 Validation criteria

\begin{tabular}{lc}
\hline Quality Score & Statement \\
\hline $3,26<\overline{\mathrm{x}}$ & Very Vality Aspect Validitas \\
$\leq 4,0$ & \\
$2,51<\overline{\mathrm{x}}$ & Valid \\
$\leq 3,26$ & \\
$1,76<\overline{\mathrm{x}}$ & Adequate \\
$\leq 2,51$ &
\end{tabular}




\begin{tabular}{|c|c|}
\hline $\begin{array}{l}1,00<\bar{x} \\
\leq 1,76\end{array}$ & Less \\
\hline \multicolumn{2}{|c|}{$\begin{array}{l}\text { In addition to expert validation, e-module products } \\
\text { will also be their practicality. By giving a response } \\
\text { questionnaire to } 1 \text { teacher and } 5 \text { students at the small } \\
\text { group product trial stage. The criteria used are based on } \\
\text { the table below [25]. }\end{array}$} \\
\hline \multicolumn{2}{|c|}{ Table 2. Modification of practicality criteria } \\
\hline Quality Score & Statement Quality Aspect Practicality \\
\hline $3,26<\bar{x} \leq 4,0$ & Very Practical \\
\hline $\begin{array}{l}2,51<\bar{x} \\
\leq 3,26\end{array}$ & Practical \\
\hline
\end{tabular}
$1,76<\overline{\mathrm{x}}$
$\leq 2,51$
$1,00<\overline{\mathrm{x}}$
$\leq 1,76$
Adequate
Less

\section{RESULT AND DISCUSSION}

\subsection{Experts validation}

The final validation data by three expert material validators, apart from tabular form, can also be presented in graphical form. The following is the data from the validation results of three material experts on each aspect in graphical form.

Table 3. Data result value validation by material expert

\begin{tabular}{|c|c|c|c|c|}
\hline \multirow{2}{*}{ No } & \multirow{2}{*}{ Aspect of Assesment } & \multicolumn{3}{|c|}{ Result Value Validation } \\
\hline & & $\mathrm{I}$ & II & III \\
\hline 1 & Content Component & 3,34 & 4,00 & 3,67 \\
\hline 2 & Linguistic Component & 3,67 & 4,00 & 3,67 \\
\hline 3 & Serving Component & 3,00 & 3,83 & 3,50 \\
\hline 4 & Graphic Component & 3,57 & 4,00 & 3,85 \\
\hline
\end{tabular}

Based on Table 3. It can be seen the comparison of the assessments of each material expert. Thus, the results of the material expert's assessment of all aspects received an average score of 3,67 . Based on the results of the assessment, it can be concluded that the interactive emodule developed is in the range of 3,67 < (x) 4.0.
Interactive teaching materials integrated independent learning on statistical materials stated in very valid criteria.The following is a revision of the material on the integrated interactive e-module for independent learning on statistics material.

Table 4. Revision from material expert

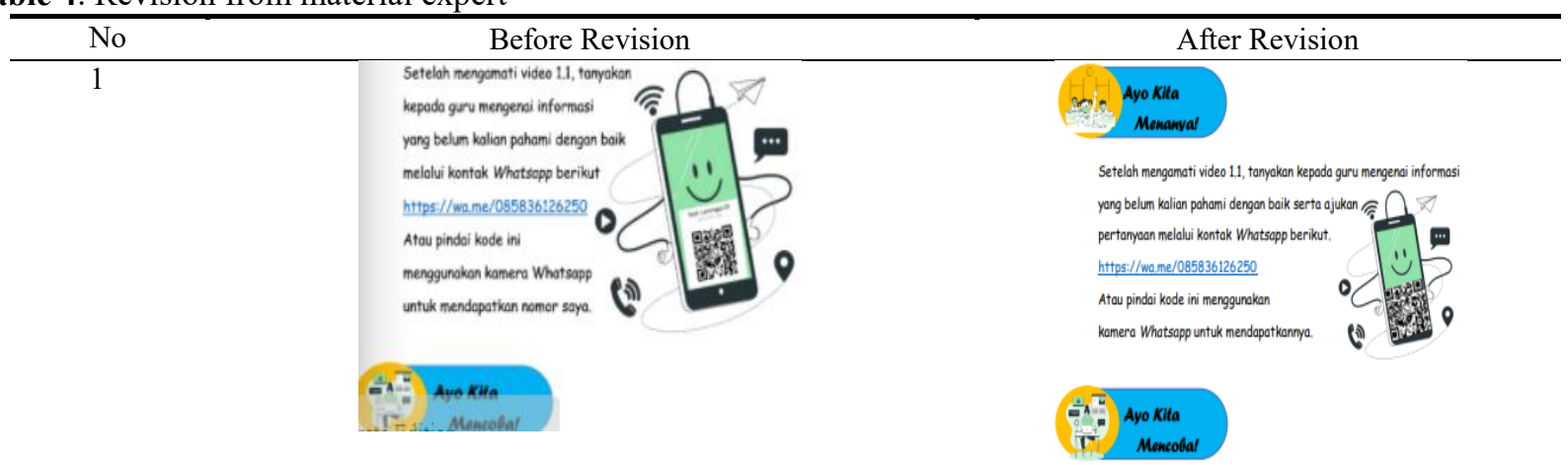




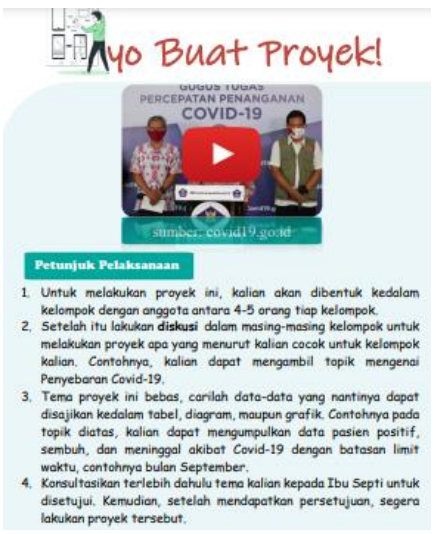

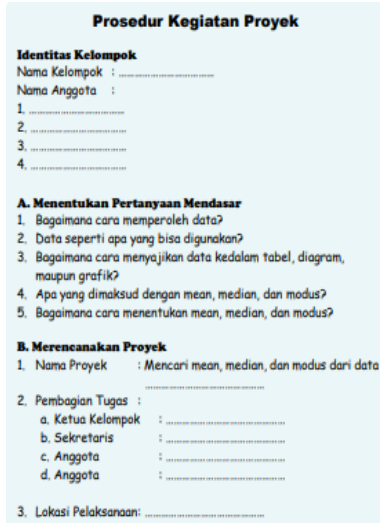

\subsection{Media Validation}

The final validation data by three media validator experts other than in tabular form can also be presented in graphical form. The following is the data from the validation results of three media experts on each aspect in graphic form.

Table 5. Data Result Value Validation by Media Experts

\begin{tabular}{llccc}
\hline \multirow{2}{*}{ No } & & \multicolumn{3}{c}{ Result Value Validation } \\
\cline { 3 - 5 } & & & I & III \\
\hline 1 & Component & 3,25 & 3,92 & 4,00 \\
2 & Content & 3,33 & 3,92 & 3,33 \\
3 & Interface & 3,50 & 3,75 & 3,58 \\
4 & Interactivity & 3,00 & 3,50 & 4,00 \\
5 & Technology & 4,00 & 4,00 & 4,00 \\
\hline
\end{tabular}

Based on Table 5, It can be seen the comparison of the assessments of each media expert. Thus, the results of the media expert's assessment of all aspects received an average score of 3,26. Based on the results of the assessment, it can be concluded that the interactive emodule developed is in the range of $3,26<$ (x) 4,0.
Interactive teaching materials integrated independent learning on statistical materials stated in very valid criteria. Revisions from media experts suggest that illustration images can be designed in various ways for each sub-material so that they are not seen repeatedly.

Table 6. Revision of illustration image on media expert validation

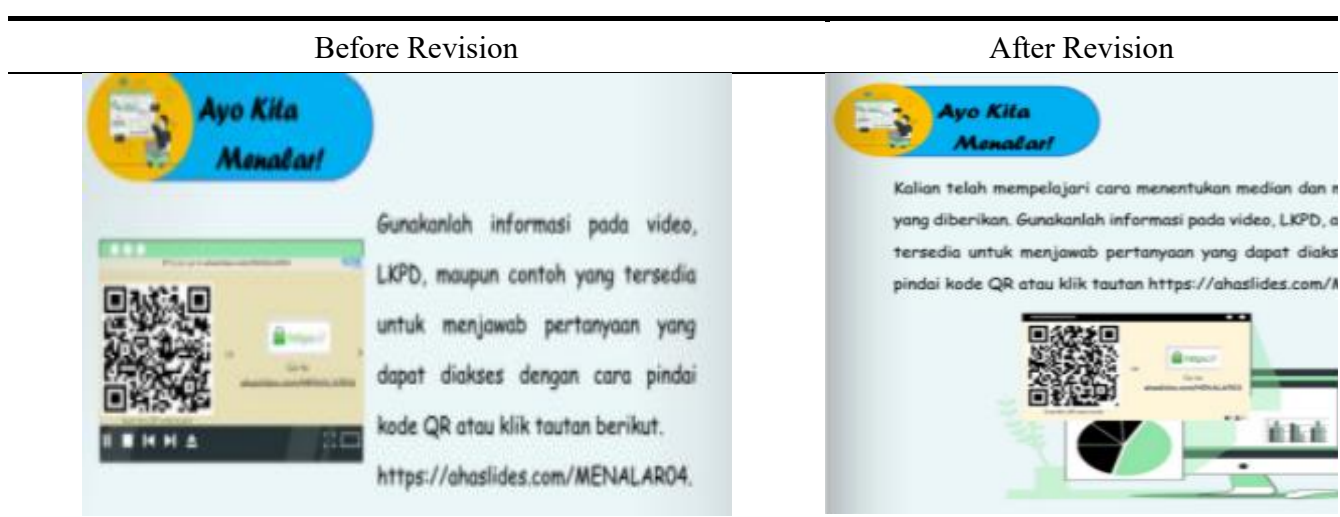




\subsection{Development Trial}

The development trial is a stage that is carried out when the product has been completed at the repair or revision stage in accordance with the suggestions and input from the material and media validator experts. This stage aims to determine the practicality after the product is declared valid or feasible by the validator experts. The implementation of the interactive e-module product trial is through the process of testing the responses of students and mathematics educators. The student response trials were carried out by 15 students representing class VIII of MTs Negeri 2 Medan and were selected heterogeneously based on the ability level of students and gender The product test results data can be seen in the following table

Table 7. Response test results

\begin{tabular}{ccccc}
\hline No. & Response Trial & Aspects & \multicolumn{2}{c}{ Analysis Results } \\
\cline { 4 - 5 } 1. & Students & & $\overline{\boldsymbol{x}}$ & criteria \\
\hline 2. & Teacher & Practical & 3,50 & Very Practical \\
& & & 3,64 & Very Practical \\
\hline
\end{tabular}

Based on the results of the questionnaire response analysis of students and mathematics educators, the integrated interactive e-module independent learning is feasible practically successively - respectively 3.50 $(87.5 \%)$ and $3.64(91 \%)$. So that e-modules can be categorized as very practical. This is in accordance with the practicality criteria guidelines used by researchers, namely the device is declared very practical if it has an

\section{CONCLUSION}

Based on the results of the study, it can be concluded that the integrated interactive e-module independent learning on statistical material developed using the Flip PDF Corporate Edition application is feasible from the aspect of validity and practicality. Judging from the aspect of validity, the interactive e-module has met the criteria of validity based on the assessment of material and media validators with the same average score of 3.67 in the very feasible category. As for the practical aspect, the interactive e-module has met the practicality criteria based on the results of the responses of students and mathematics educators with an average score of 3.50 $(87.5 \%)$ and $3.64(91 \%)$ respectively. very practical category. Thus, the integrated interactive e-module for independent learning on statistical material is declared feasible because it can and is very practical to use in the learning process.

\section{ACKNOWLEDGMENTS}

The authors thank Department of Mathematics, Faculty of Mathematics and Science, and Research and Community Service Institutions Universitas Negeri Medan due to the funding of BOPTN-2021 for this research. average practical validity score in the range of $3.26<$ (x)4.00.

\section{REFERENCES}

[1] Kemendikbud. Makalah Rapat Koordinasi Kepala Dinas Pendidikan Seluruh Indonesia: Pokok-Pokok Kebijakan Merdeka Belajar. Jakarta: Kementrian Pendidikan dan Kebudayaan; 2019.

[2] Hendri N. Merdeka Belajar, Antara Retotika dan Aplikasi. E-Tech. 2020, 8 : 1-9.

[3] Ainia, DK. Merdeka Belajar Dalam Pandangan Ki Hadjar Dewantara dan Releansinya Bagi Pengembangan Pendidikan Karakter. Jurnal Filsafat Indonesia. Vol 3. 2020, pp 95-101.

[4] Setiawan W. Merdeka Belajar: Konsepsi dan Implementasi pada Pengelolaan Sekolah di Era Digital. Jakarta: Kemendikbud; 2020.

[5] Lase D. Pendidikan di Era Revolusi Industri 4.0. SUNDERMANN: Jurnal Ilmiah Teologi, Pendidikan, Sains, Humaniora Dan Kebudayaan. Vol 1, 2019; pp. 28-43.

[6] Schwab K. The Fourth Industrial Revolution. Switzerland: World Economic Forum; 2016.

[7] Batubara HH. Media Pembelajaran Efektif. Semarang: Fatawa Publishing; 2020

[8] Hanafiah, Cucu S. Konsep Strategi Pembelajaran. Bandung: PT Refika Aditama; 2009. 
[9] Klein I J, Tafferas S, King H S, Commitante A, Bey L C, Stripling B. Project Based Learning: Inspiring Middle School Students to Engange in Deep and Active Learning. New York: NYC Department of Education; 2009.

[10] Sutirman. Media \& Model-model Pembelajaran Inovatif. Yogyakarta: Graha Ilmu; 2013.

[11] Daryanto. Panduan Proses Pembelajaran Kreatif dan Inovatif. Jakarta : AV Publisher; 2009.

[12] Abidin, Y. Desain Sistem Pembelajaran dalam konteks Kurikulum 2013. Bandung : Refika Aditama; 2014.

[13] Gora W, Sunarto. Pakematik Strategi Pembelajaran Inovatif Berbasis TIK. Jakarta : PT Elex Media Komputindo; 2010.

[14] Sani A R. Pembelajaran saintifik untuk Implementasi Kurikulum 2013. Jakarta: Bumi Aksara; 2014.

[15] Made W. Strategi Pembelajaran Inovatif Kontemporer: Suatu Tinjauan. Konseptual Operasional. Jakarta: PT. Bumi Aksara; 2014.

[16] Andriadi A, Fitriani D, Suhandri S. Pengembangan Modul Matematika Berbasis Active Learning Untuk Memfasilitasi Kemampuan Berpikir Kreatif Matematis Siswa Sekolah Menengah Pertama Juring: Journal for Research in Mathematics Learning. Vol, 1, 2018. pp.55-64. DOI: 10.24014/juring.v1i1.4768

[17] Fatikhah I, Izzati N. Pengembangan Modul Pembelajaran Matematika Bermuatan Emotion Quetient Pada Pokok Bahasan Himpunan. EduMa. Vol. 4. 2015, pp. 46-61. DOI: 10.24235/eduma.v4i2.29

[18] Martatianingsih U. Statistika untuk Memfasilitasi Penalaran Statis Siswa Kelas VIII SMP/MTs. Surabaya: Universitas Muhammadiyah Ponorogo; 2018.
[19] Ketut A, dkk. Pengembangan e-modul berbasis PBL Mata Pelajaran Visual Efek kelas XI multimedia di SMK TI Bali Global Singaraja. Jurnal KARMAPATI. Vol. 7, 2018, pp. 1-13. DOI:10.23887/jptk-undiksha.v13i2.8529

[20] Ilangovan P, Azween A, Muthaloo S, Ramesh K M H M, Sugumaran S. Generation Z Attitudes towards Internet Usage for E-Commerce in Selangor, Malaysia. International Journal of Engineering and Advanced Technology (IJEAT). Vol, 8, 2019, pp. 912-917. DOI:10.35940/ijrte.C1125.1083S219.

[21] Kahle D. Animating Statistics: A New Kind of Applet for Exploring Probability Distributions Journal of Statistics Education, vol. 22, 2016, pp196208.

DOI: https://doi.org/10.1080/10691898.2014.11889700

[22] Neumann DL, et al. Evaluating Computer-Based Simulations, Multimedia and Animations that Help Integrate Blended Learning with Lectures in First Year Statistics. Australasian Journal of Educational. Technology, vol 27. 2011, pp.274-289. DOI:10.14742/ajet.970

[23] Trianto. Model Pembelajaran Terpadu Konsep, Strategi, dan Implementasinya dalam Kurikulum Tingkat Satuan Pendidikan. Jakarta: Bumi Aksara; 2010.

[24] Rizky S, Nego L. Pengembangan Bahan Ajar Program Linear Berbasis Kontekstual dan ICT. Jurnal Pendidikan Matematika FKIP Univ. Muhammadiyah Metro. Vol. 5 2016, pp. 139-148. DOI: https://doi.org/10.24127/ajpm.v5i2.674

[25] Masykur, Rubhan, et al. Pengembangan Media Pembelajaran Matematika dengan Macromedia Flash. Al-Jabar: Jurnal Pendidikan Matematika. Vol 8, 2017. pp177-185. DOI: https://doi.org/10.24042/ajpm.v8i2.2014. 